Better Off,

\section{But Still on the Farm}

\author{
Harlan B. Miller \\ Virginia Tech
}

A review of Farm Animal Welfare: Social, Bioethical, and Research Issues, by Bernard E. Rollin (Iowa State University Press, 1995) pp. xii + 168, ISBN 0-8138-2563-6, $\$ 29.95$

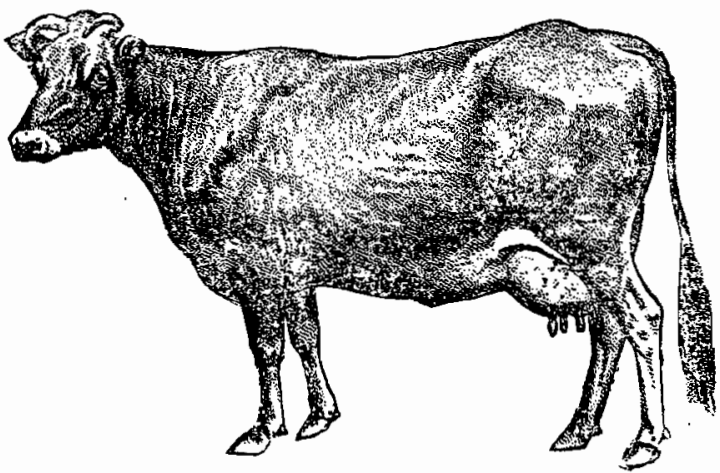

\section{The Authors}

This book, valuable but intermittently irritating, appears to have been written by two distinct Bernard E. Rollin personalities. One of them is Bernard E. Rollin the meliorist philosopher. BER-MP (as I shall henceforth refer to him) became well known with Animal Rights and Human Morality (first edition 1981, second edition 1992). He is a meliorist rather than an abolitionist inasmuch as he believes that significant animal use, especially for food, is here to stay and need not be morally objectionable. He holds, however, that very much existing animal use fails to meet minimal moral standards. The lot of animals in human hands must be significantly ameliorated. Distinctive of the ethical analysis of BER-MP is the notion of an animal's telos, the complex of desires and behaviors or more generally of ways of being, of acting, and of relating to one's conspecifics, that are natural for a member of the species. To prevent an animal from living in accordance with its telos is to deprive it of a minimally decent life.

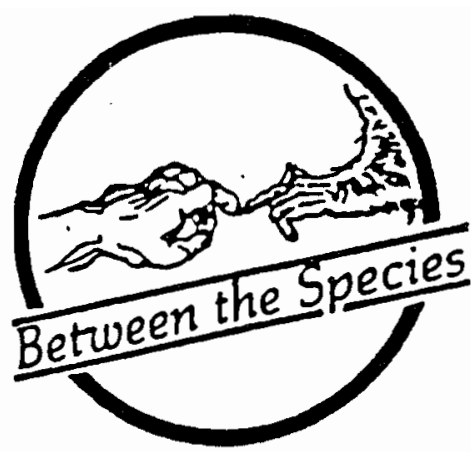

So BER-MP's focus is not on welfare or suffering (though of course preventing natural behavior causes frustration, and pain and terror inhibit telic behavior). Neither is it on a general notion of inherent value or of rights to equal consideration. Animals must not be abused, and especially must not suffer the profound frustration of being prevented from realizing their teloi. But there is no necessary incompatibility, BER-MP holds, between respecting an animal's telos and raising it for slaughter.

The second author is Bernard E. Rollin the agribusiness tactician. I'll call him BER-AT. This personality doesn't seem to be a philosopher at all. He speaks the language of prudence, not that of duty. He has no views whatever about animal welfare. He's responsible for the 'social' in the book's subtitle. Consumers and voters, increasingly, are concerned about farm animal welfare as they perceive it. (Are they right? Are they wrong? BER-AT doesn't care-it's not his job.) BER-AT"s job is to advise agribusiness about this threat to current and future profits. Worried about flooding? Build a levee and buy insurance. Worried about animal welfare concems? Change some practices and fund some research.

I've known BER-MP slightly, and his works extensively, for many years, and thought well of both. BER-AT, however, is new, at least to me and at least in the strength he has here.
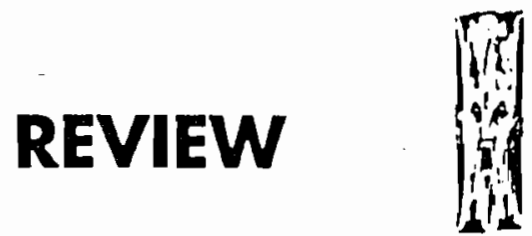


\section{2 - The Structure of the Book}

The basic structure and overall aims of the book appear to have been determined by BER-AT. The intended audience is clearly practitioners of production animal agriculture in all its stages, especially producer's associations and any other entities capable of funding research, and the supporting elements of the agribusinessgovernment complex (the U.S. Department of Agriculture, state agencies, the land-grant universities, etc.).

Part 1 consists of two chapters, one describing the threat, the "New Social Ethic for Animals," and one describing the ways in which scientific research on animal welfare can provide defenses against the threat.

Part 2 consists of five chapters on specific forms of animal agriculture, welfare issues for each, and suggestions for lines of research. There are chapters on beef, swine, dairy, veal, and poultry. (There is no chapter on sheep, and the poultry chapter is concerned only with chickens.)

There is a brief final chapter of reflections on production agriculture in general.

BER-AT sets the agenda, but the voice of BER-MP is heard again and again, least clearly in the first and third chapters, most clearly in the sixth (veal) and last.

\section{3 - The "New Social Ethic"}

In the good old days, BER-AT tells us, traditional agricultural practices prevented, as a rule, the abuse of animals in agriculture. Good husbandry was good business and the producer's interests and those of the animals pretty well coincided.

Society, therefore, did not need laws mandating good husbandry for animals--that was dictated by self-interest and reinforced by the ancient ethic of care. If a person did not care about self-interest, he or she was unlikely to be persuaded by laws.... This, in turn, explains why the traditional social consensus ethic for the treatment of animals-the anticruelty ethic... could be so minimal and yet socially adequate. (p. 7)

This romantic picture of traditional agriculture is hard to take very seriously. It is, in fact, undermined and sometimes just contradicted repeatedly in this very book by what I take to be insertions by BER-MP. One of them, on rodeo, shows up later in the very paragraph from which I have just quoted.

Real or imaginary (or, more likely, a bit of each), traditional practices of good husbandry, telosrespecting if not always benevolent, no longer govern agricultural practice. In some areas (cattle on range), they have been undermined. In others (chickens, veal calves), they have just been extirpated. Modern animal agriculture is capital-intensive, animal-intensive, and husbandry-poor (it is not just that there are too few workers to attend to the needs of individual animals but that the mindset and wage structure of intensive agriculture actively discourage such attention). Further, much modern animal agriculture is confinement agriculture, and confinement invariably frustrates drives central to the teloi of the animals confined. Things have changed for the animals, and changed much for the worse.

Human society has changed as well. We have moved from the farms into the city, losing direct contact with agriculture. The mass media have exploited our fascination with animals. To these two points by BERAT, BER-MP adds that society has been progressively opening itself to concern for hitherto neglected or excluded groups, with nonhuman animals a natural next step in the expansion. Pro-animal arguments by philosophers (including, of course, BER-MP himself) have reached a wider and wider audience.

The result is a "new social ethic for animals." A large majority of Americans are concerned about the treatment of animals. A remarkable number are willing to ascribe rights of some sort to nonhuman animals. But an even larger majority of Americans believes that it is permissible for us to consume animals as food. BER-AT takes this 'ethic' as his point of reference. We will continue to raise and consume animals, but the welfare of the animals must be improved (and most important, must be perceived as improved), even if the result is increased costs.

Is the "new social ethic" coherent? Can we really believe both that animals have some sort of moral claim to concern (never mind the philosophical distinctions between rights, welfare, and so on) and that it is permissible raise and kill them (or even just to inconvenience them) simply because we are accustomed to certain forms of food? BER-AT, as I have already mentioned, is simply not interested in this question. But BER-MP is quite interested in questions of coherence, and he raises a number of them in this book. ${ }^{1}$ Not, 
however, this big one. The coherence of the "new social ethic" is neither challenged nor defended.

The purpose of the book is to survey problems of animal welfare in production agriculture with an eye toward removing or reducing those in conflict with the "new social ethic." As this is sketched out, one of the most striking of the many conflicts between the two authorial personalities almost leaps off the page. In the last paragraph of p. 23, BER-MP emerges to rebut the dismissal of critics of intensive agriculture as uninformed.

Contrary to the beliefs of some elements of the agricultural community, however, it will not help to "educate" the public. In fact, if the public knew more about the way in which agricultural animal production infringes on animal welfare, the outcry would be louder.... Plainly, if the public knew... it would be more, not less, hostile to current agriculture. [ellipses mark omission of three examples]

In the very next paragraph (first on p. 24), BER-AT is back in control and, ignoring his other half like a splitbrain patient, warns that

... the agricultural community should develop its own legislation before uninformed legislation is thrust on it.

“Uninformed legislation"?

\section{4 - Welfare Research}

Research on animal welfare is central to the solutions BER-AT offers agribusiness. But is it even possible to study welfare scientifically? That is the question addressed by the second chapter. Here BER-AT passes the baton to BER-MP. The result is a much more coherent and much more satisfactory chapter. Four beliefs stand in the way of animal welfare research.

1. The view that animal welfare and animal rights represent a clear-cut dichotomy, separated by an unbridgeable gulf. Animal welfare is perceived as an acceptable concern of producers; animal rights is denied any legitimacy. This opinion is held strongly by producers, agricultural scientists, and veterinarians and is essentially never questioned.
2. The conviction that one can talk of animal welfane in a value-free, objective, factual context. Again, this view is held by all elements of agriculture but is elicited most easily from scientists, who are steeped in the belief that science is value-free.

3. The general principle that science and ethics are radically separated, with science having no connection to ethics.

4. The notion that research into animal welfare cannot address, in any scientific way, issues pertaining to animal consciousness or animal feeling, including felt pain and suffering. (p. 27)

Most of Chapter 2 consists of the systematic destruction of these four claims, in the order given. It is vintage BER-MP. That is, it is first rate.

\section{5 - The Affirmative Ad Hominem}

The first of the chapters on types of animal agriculture is on cattle ranching. BER (both AT and MP) is clearly fond of, or at least favorably impressed by, many ranchers. So much so, in fact, that he slips into a fallacy I'm going to call the affirmative ad hominem.

It is customary to distinguish two or three varieties of the fallacy known as 'ad hominen' (to the person). The most common is the abusive ad hominem, of the form "So-and-so is a rotten person, and So-and-so believes that $\mathrm{P}$ is true. Therefore $\mathrm{P}$ is false." These completely worthless arguments are depressingly common. I have on at least three occasions been assured that animal research is uniformly morally acceptable because the people at PETA are a bunch of degenerates.

I hereby christen as 'affirmative ad hominem' another seriously defective form of argument. The form is " $\mathrm{A}, \mathrm{B}$, and $\mathrm{C}$ are decent people. A, B, and C participate in practice $X$. Therefore practice $X$ is morally acceptable." Very little reflection should be required to see the fallaciousness of this argument. Most of my ancestors were probably decent people, by the light of their times. Most people are. Yet many, in fact almost all, of my ancestors (yours too, gentle reader) supported or acquiesced in systems of slavery, racial and sexual oppression, and (pace Rollin) brutal treatment of animals.

In this book, affirmative ad hominem arguments are concentrated in Chapter 3. These more-or-lesstraditional cattle ranchers are wonderful folks. Therefore the practice of (at least more-or-less-traditional) cattle 
ranching must be quite all right. BER-MP knows, must know, that this is a dreadful argument. But affection clouds his mind. ${ }^{2}$

\section{6 - Varieties of Animal Agriculture}

All of the chapters on specific forms of production agriculture will be of great value to anyone interested in farm animal welfare. The references are extensive and illuminating. (Unfortunately, the notes are at the end of the volume rather than at the foot of the page, where they belong. Certainly Iowa State press uses computer typesetting. There's just no excuse for a major press to persist in outmoded and quite inconvenient note placement.) Unless you're exceptionally well acquainted with all these forms of animal agriculture, you will learn much. (Until I read this book, I'd never heard of a gomer bull.)

The tension between BER-AT and BER-MP is highest, as I have already indicated, in the chapter on cattle ranching. This chapter contains (a) valuable descriptive information, (b) paeans of praise for the traditional ranching ethos, and (c) incisive criticism of that ethos as morally incoherent. The American tradition of cattle ranching involves castration, dehorning, and branding, none of which are necessary and all of which cause considerable suffering. Less central to the tradition is the gratuitous rough treatment of cattle BER-MP calls "cowboying." Cowboying is really a form of entertainment, a gratifying demonstration of macho mastery (not limited, alas, to males). The rodeo is to cowboying what college or professional basketball is to pickup playground basketball. BER-MP points out that many people immersed in the ranching tradition are uncomfortable about cowboying and, a fortiori, about rodeo. But very few show real concern about the more central practices of castration, branding, and dehorning. ${ }^{3}$

The presence of BER-MP increases even further in the next chapter, on swine. The discussion of the natural behavior (i.e. the telos) of swine is fascinating, and the criticism of routine tail docking and other responses to the 'vices' created by confinement and overcrowding is impressive. (The attack on the vice of 'vice' talk is just the sort of thing BER-MP does best.)

The treatments of diary farming and of poultry are both quite impressive. I found the criticism of debeaking exceptionally useful because of the powerful scientific evidence BER-MP musters. In both chapters, the telos analysis plays a major role.
In the sixth chapter, on veal, BER-AT is almost entirely absent. Confinement veal raising is portrayed as an abomination, rejected not only by the "new social ethic" but by cattle ranchers, some of them moved to tears by films of calves in crates.

\section{7 - Human Farm Animal Welfare}

In the short and schematic concluding chapter, BERAT is back. But in these very general reflections on the state of American agriculture, he and BER-MP have something important to teach us. There are human animals down on the farm, too, and they're not doing very well. The transformation of agriculture that put chickens in cages and cows in crates also put farmers in debt, or at the mercy of a merciless market, or just out of business. The family farm is effectively extinct, replaced by the factory, the multinational corporation, and those it has effectively reduced to sharecropper status, or the economically marginal operation in which every human adult has another full-time job.

Rollin sketches a dream of a future in which people can lead a good life on the farm. Those of us to the 'left' of him on animal treatment should also have such a vision, a vision of more people living better on less land, supplying the rest of us with healthy food, almost certainly at higher cost. (There's no free lunch, and no free breakfast or dinner, either. The costs that have been borne by the nonhuman animals, by the environment, and by exploited and displaced farm families, will have to be distributed somehow.) Rollin's dream isn't mine because in his, animals are still being raised for food. But it is an answer to the perfectly reasonable question, "What happens to the farmers?" That is a question that deserves an answer.

\section{8 - Meliorists and Abolitionists}

How should an abolitionist (one who believes it morally obligatory to abandon the consumption of animals) react to this book, or for that matter, to meliorist proposals of any sort? Purists of a certain sort will simply denounce them as compromises with evil. Purists of another sort might condemn them on the grounds that, if the lot of farm animals really were to be substantially ameliorated, the momentum of the movement for complete liberation would be substantially reduced. Abolitionists of this sort would prefer for the chickens to remain in the cages, debeaked, perhaps even for the 
calves to remain in the crates, in order to 'radicalize' ordinary citizens by confronting them with these horrors. Tactically, then, such an abolitionist should loudly praise this book in order to taint it in the eyes of the agribusiness establishment.

I confess that I'm not much of a purist here, but I don't know whether that is because I think mass transformation by radicalization is wildly unlikely in this case, or because I'm just a weak-willed compromiser. Adoption of the sorts of reforms championed in this book would relieve vast animal suffering and frustration. Very many animals would be much better off. That is, I believe, a very good reason to hope that BER-MP and even BER-AT get the ear of the establishment. Further, if these became the standard positions of agribusiness, the center of gravity of the debate would have shifted a long way in 'our' direction. (Tactically, that might mean that we should denounce this book as violently and luridly as possible as a compendium of sadism, thus drawing the other side to its defense. So suppress this review.)

Read this book.

\section{Notes}

${ }^{1}$ See, for example, the critique of some research practices on Kantian grounds on p. 47.

${ }^{2}$ So much so, in fact, that he complains of "cheap shots" at the noble ranchers (p. 57), and fires off his own cheap shots at unnamed strawpersons ("producing meat protein in fermentation vats") (p.52).

3 "Cowboying" is depressingly common all over the country, not just in Rollin's West. On two occasions, agricultural scientists have expressed concern about it to me. It should be noted that they knew they were talking to an abolitionist. Intellectual honesty outweighed political prudence. There are many decent people involved in production animal agriculture.

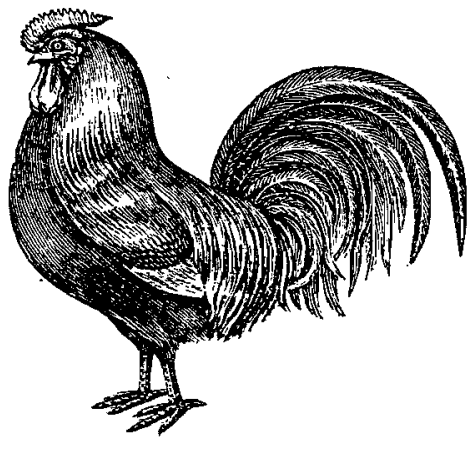

\section{Response: Seeing Double}

\section{Bernard E. Rollin \\ Colorado State University}

Since a great many people are extremely uncomfortable in a world containing only one Bernard Rollin, Harlan Miller's suggestion of two Rollins is certainly unacceptable in the better world we all hope to build. In what follows, I will do my best to unify the disparate Rollins that he finds speaking in my Farm Animal Welfare.

Professor Miller is absolutely correct in his assumption that the primary audience for the book is the people who are in fact responsible for contemporary agriculture in the United States-producers, USDA, and agricultural scientists. It was, in fact, USDA that contracted with me for the study that resulted in this book. Specifically, I was asked to explain to USDA in particular, and to the powerful agricultural community in general, why they should care about, attend to, or spend any money to improve, farm animal welfare. After all, these are people who tend to believe

1. that science is ethics-free

2. that the goal of agriculture is efficiency and productivity

3. that if there is any sense to the notion of ethics underlying agricultural practice, it is the moral imperative to produce cheap and plentiful food, and lastly, therefore

4. that animal agriculture is fine the way it is and should be altered only to create greater efficiency and productivity.

Among the few who have reflected on the notion of animal welfare, it is dogma that

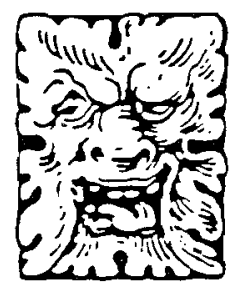

